\title{
A Drowned Diver - Four Expert Witness Opinions - Who is Right?
}

\author{
Hrvoje Lalić \\ University, Rijeka, Croatia \\ Edited by: Igor Spirosk \\ Citation: Lalić H. A Drowned Diver - Four Expert Witnes \\ Opinions - Who is Right? Open Access Maced J Med Sci. \\ 2021 May 14, 9(C).52-54. \\ https://doi.org/10.388/camjis. 2021.5921 \\ Keywords: Expertise, Ding; Occupational medicin \\ Occupational Medicine, Rijeka - 51000 , Croatia \\ Occupational Medicine, Rijeka - 51000, Croatia. \\ Received: 23-Feb-202 \\ Revised: 29-Mar-2021 \\ Accepted: 04-May-202 \\ Copyright: $\odot 2021$ Hrvoje Lalic \\ Funding: This research did not receive any financial \\ Competing Interest: The authors have declared that nort \\ competing interest exists \\ Open Access: This is an open-access article distribute \\ Commercial 4 . O International License (CC BY-NC 4.0)
}

Department of Occupational and Sports Medicine, Specialist in Occupational Medicine, Health Centre and Medical School

\begin{abstract}
BACKGROUND: The paper describes the case of a drowned diver in the Adriatic Sea near Pula, Croatia.

CASE PRESENTATION: The deceased diver had not been trained at any Health and Safety at Work programs nor had he been examined by the occupational medicine (OM) specialist. The pathologist in Pula concluded that this accident was caused by drowning and that diver's blood was saturated with $38 \%$ carboxyhemoglobin $(\mathrm{COHb})$. The second pathologist in Zagreb concluded that the diver drowned due to atherosclerosis sickness but that $\mathrm{COHb}$ was not present in his blood. The third expert witness from Forensics in Rijeka evaluated that the diver died due to increased exertion while diving, due to atherosclerosis and weakened heart. The fourth, the OM specialist expert witness from Rijeka, explained that the diver was a healthy athlete who died due to faulty diving equipment

CONCLUSION: Persons who work under the special working conditions should be examined at an Occupational medicine department as well as trained for work in a safe way. Periodical examinations and permanent training courses should be provided. That way the risk of fatal accidents would be reduced to a minimum.
\end{abstract}

\section{Introduction}

Diving and hyperbaric medicine has first of all been military medicine specialty, but over the time diving also developed commercially, as well as a sports and recreational discipline [1]. To prevent fatal accidents, developed countries follow elaborate official rules for controlling the above mentioned activities and therefore fatal accidents are very are [2]. Diving medicine demands elaborated practical guidelines that need trained medical staff [3]. To be evaluated as fit for diving, the candidates must be sent to strict preventive medical examinations [4].

This paper describes the death by drowning in the Adriatic Sea in Istria, near Pula, Croatia. The Public Prosecutor of the Republic of Croatia started forensic investigation of this death case.

\section{Case Report}

Here is presented a case of deceased professional, commercial diver, (born in 1967), who went diving with another diver, his employer, the shell fishing business owner.

After an hour and half of diving, the boss came to the sea surface and spotted his employee fellow diver straggling to gain the vertical position. He hurried to his help and dragged him to the coast where he tried to resuscitate him, after approximately 15 min came ambulance but reanimation failed and 20 min later the diver was proclaimed dead.

As this was a fatal accident at work, on the scene arrived the police, State Inspector and Health and Safety at Work inspector. In cases like this ID has to be provided along with the occupational medicine (OM) health evaluation certificate, certificate for training for work under special conditions, as well as the health and safety at work certificate. The employer had not been able to provide any of the above mentioned certificates as he did not manage his staff according to law.

The public prosecutor ordered autopsy. At the pathology in Pula was found atherosclerotic changes on the blood vessels and enlarged heart, congestive lungs with emphysema, brain edema, and eye ecchymosis. Pathologist issued the statement that death was caused by drowning as well as the presence of $38 \%$ carboxyhemoglobin $(\mathrm{COHb})$ from an unknown source in blood.

The tissue samples are also sent to pathology in Zagreb. The pathologist issued a statement that the death was caused due to deceased diver's poor general health due to atherosclerosis, while $\mathrm{COHb}$ in blood was not found.

The compressed air tank was sent at the Centre for Forensic Investigation. It was found that the 
15 I - tank contained $78 \%$ nitrogen, $20 \%$ oxygen, and $0.04 \%$ carbon dioxide. The pipe that comes out of the tank to the buoyancy regulator was broken.

Engaged was also the Forensic Medicine expert witness from Rijeka and he concluded that the diver had an impaired heart that was enlarged, which during physical exertion failed, thus causing death by drowning.

Finally, the OM specialist from Rijeka explained that the diver was a healthy athlete and that he died due to damaged scuba diving equipment.

\section{Discussion}

Although the diver never attended a Health and Safety at Work course, he did, 14 years previous to the fatal accident, pass a $259 \mathrm{~h}$ training for commercial fishing divers. Thus, this is not a case of an amateur who, for example, panicked or vomited in their mask due to consumption of fizzy drinks or alcoholic beverages before diving [5]. Although the drowned diver had a basic diving knowledge and was an experienced diver, that does not free his employer of guilt of not providing a Health and Safety at Work training for this specific job on a fixed-term contract. Further, every immersion has to be reported so that emergency help like helicopter transport can be organized immediately [6]. According to pathologists, the elevated level of $\mathrm{COHb}$ (if so, for one pathologist reported $38 \%$ of it in blood and the other did not find any) was surely not caused by liver disease, cirrhosis, as the autopsy confirms [7]. COHb sources are often generated from houses, faulty chimneys, or engine exhaust gases [8]. Persons who work under the special working conditions should be examined at an Occupational medicine department as well as trained for work in a safe way. Periodical examinations and permanent training courses should be provided. That way the risk of fatal accidents would be reduced to a minimum [9]. Inhaled compressed air with water vapor which has an impact on breathing regulator was also described as the cause of elevated levels of $\mathrm{COHb}$. $\mathrm{CO}$ as a gas poisoning was also described in an isolated case of commercial diver, when breathing compressed air [10].

Hypoxemia can easily also cause mental confusion [11]. Psychological state must be at the upper level of the average to achieve guaranties for calmness and stability. Divers often also manifest neurological disorders due to the fact that bubbles released during emerging out can enter not only brains but also the spinal cord [12]. Hearing apparatus must be too, because changes during pressure equalization can cause vertigo and disorientation that can be fatal for the diver [13]. The deeper diver dives, the greater the danger becomes [14].
This diver was not medically examined; therefore, it was not possible to act preventively and this brings one to the importance of an early diagnosis. After he died it was very difficult to come to the right conclusion, because later many items go to the domain of speculations [15].

The OM specialist as the only clinician of the above-mentioned expert witnesses; in this case, concludes that the diver was healthy. The atherosclerotic plaques (macroscopic findings of the pathologists) on diver's blood vessels and on the cardiac endothelium were not of such a size that they stopped or narrowed free circulation and thus as such had clinical effects. The OM specialist was asked by the Public Prosecutor whether the deceased diver would passes the OM examination positively. In conclusion, the diver would have most likely passed the examination at the OM. The probable findings of enlarged heart chamber on the electrocardiogram are presented with higher $\mathrm{R}$ and deeper S marks which do not present contraindications for diving. An athletic heart should be distinguished from a myocardiopatic heart.

The OM specialist from Rijeka explained that the diver was a healthy athlete and that he died due to damaged diving equipment, probably of compressed air failure.

\section{Conclusion}

The diffusing capacity for carbon monoxyde and nitric oxyde after 8 hours of diving showed significant reduction in divers breathing $100 \%$ oxygen compared with divers breathing compressed air.

\section{References}

1. Chong SJ, Liang W, Kim SJ, Kang WL. Future synergism in diving accident management: The Singapore mode. Diving Hyperb Med. 2010;40(1):41-3

PMid:23111838

2. Mollerlokken A. The future of diving research in Norway. Diving Hyperb Med. 2018;48(2):72.

PMid:29888377

3. Ching J, Low CT, Kang WL. The development of hyperbaric and diving medicine in Singapore. Singapore Med J. 2011;52(12):901-5

PMid:22159934

4. Gilliam B. A personal overview of accidents and risk management in the recreational diving industry. Diving Hyperb Med. 2010;40(3):156-9.

PMid:23111912

5. Petri NM, Sipancevic H, Sutlovic D, Gojanovic MD. Death of scuba diver caused by vomiting and panic: A case report. Am J 
Forensic Med Pathol. 2011;32(2):186-9. https://doi.org/10.1097/ paf.0b013e3181d3de7a

\section{PMid:20190635}

6. Corgie L, Huiban N, Pontier JM, Brocq FX, Boulard JF, Monteil M. Diving accident evacuations by helicopter and immersion pulmonary edema. Aerosp Med Hum Perform. 2020;91(10):806-11. https://doi.org/10.3357/amhp.5563.2020 PMid:33187567

7. Parola M, Pinzani M. Liver fibrosis: Pathophysiology, pathogenetic targets and clinical issues. Mol Aspects Med. 2019;65:37-55. https://doi.org/10.1016/j.mam.2018.09.002 PMid:30213667

8. Ramirez HB, Alvarez RF, Cuadrado GR, Gonzalez CM, Jerez FR, Clara PC. Elevated carboxyhemoglobin: Sources of carbon monoxide exposure. Arch Bronchopneumol. 2014;50(11):465-8. https://doi.org/10.1016/j.arbr.2014.09.009 PMid:24809679

9. van Ooij PJ, van Hulst RA, Houtkooper A, Sterk PJ. Nitric oxide and carbon monoxide diffusing capacity after a 1-h oxygen dive to $9 \mathrm{~m}$ of sea water. Clin Physiol Funct Imaging. 2014;34(3):199208. https://doi.org/10.1111/cpf.12082 PMid:24034178

10. Holt J, Weaver LK. Carbon monoxide poisoning mimicking arterial gas embolism in a commercial diver. Undersea Hyperb Med. 2012;39(2):687-90.
PMid:22530451

11. Blatteau JE, Morin J, Roffi R, Druelle A, Sbardella F, Castagna O Clinical problem solving: Mental confusion and hypoxaemia after scuba diving. Diving Hyperb Med. 2020;50(2):181-4. https://doi. org/10.28920/dhm50.2.181-184

PMid:32557423

12. Louge $P$, Gempp E, Constantin P, Hugon M. Current management of diving related spinal cord decompression sickness in 2010 Press Med. 2010;39(7-8):778-85.

PMid:20466511

13. Kitajima N, Sugita-Kitajima A, Kitajima S. Altered Eustachian tube function in SCUBA divers with alternobaric vertigo. Otol Neurotol. 2014;35(5):850-6. https://doi.org/10.1097/ mao.0000000000000329

PMid:24751737

14. Blatteau JE, Lambrechts $\mathrm{K}$, Ruffez J. Factors influencing the severity of long term sequelae in fishermen divers with neurological decompression sickness. Iving Hyperb Med. 2020;50(1):9-16. https://doi.org/10.28920/dhm50.1.9-16 PMid:32187612

15. Smithuis JW, Gips E, van Rees Vellinga TP, Gaakeer MI. Diving accidents: A cohort study from the Netherlands. Int J Emerg Med. 2016;9(1):14. https://doi.org/10.1186/s12245-016-0109-4 PMid:26968856 